\title{
GROWTH AND PRODUCTION OF SUNFLOWER AS A FUNCTION OF CATIONIC NATURE OF THE WATER AND NITROGEN
}

\author{
CRESCIMENTO E PRODUÇÃO DO GIRASSOL EM FUNÇÃO DA NATUREZA \\ CATIÔNICA DA ÁGUA E NITROGÊNIO
}

\author{
José Raimundo de SOUSA JÚNIOR ${ }^{1}$; Geovani Soares de LIMA ${ }^{2}$; \\ Vera Lúcia Antunes de LIMA ${ }^{3}$; Hans Raj GHEYI ${ }^{3}$; Jônatas Raulino Marques de SOUSA ${ }^{4}$; \\ Elysson Marcks Gonçalves ANDRADE ${ }^{4}$; Lauriane Almeida dos Anjos SOARES ${ }^{5}$ \\ 1. Mestrando em Engenharia Agrícola, Universidade Federal de Campina Grande - UFCG, Campina Grande, PB, Brasil; 2. Pós- \\ Doutorando em Engenharia Agrícola, PNPD/CAPES, UFCG, Campina Grande, PB, Brasil. geovanisoareslima@gmail.com; 3. \\ Professor, Doutor, UFCG, Programa de Pós-Graduação em Engenharia Agrícola, Campina Grande, PB, Brasil; 4. Doutorando em \\ Engenharia Agrícola, UFCG, Campina Grande, PB, Brasil; 5. Pós-Doutoranda em Engenharia Agrícola, PDJ/CNPq, UFCG, Campina \\ Grande, PB, Brasil.
}

\begin{abstract}
In the Brazilian semi-arid region, it is common to find water with high concentration of salts and with variation in its cationic nature. Thus, we aimed to evaluate the growth and production components of sunflower, cv. BRS 324, as a function of irrigation water of different salinity levels and cationic nature associated with doses of nitrogen (N). The experiment was conducted in pots, under open field conditions, in the municipality of Campina Grande-PB, Brazil, in a randomized block design in $5 \times 5$ factorial scheme, with three replicates, based on five treatments of salinity and cationic nature of the water $-\mathrm{S}\left(\mathrm{S}_{1}-\mathrm{Control} ; \mathrm{S}_{2}-\mathrm{NaCl} ; \mathrm{S}_{3}-\mathrm{CaCl}_{2} ; \mathrm{S}_{4}-\mathrm{KCl}\right.$ and $\left.\mathrm{S}_{5}-\mathrm{NaCl}+\mathrm{CaCl}_{2}+\mathrm{MgCl}_{2}\right)$ combined with five $\mathrm{N}$ doses $\left(50 ; 75 ; 100 ; 125\right.$ and $150 \mathrm{mg}$ of $\mathrm{Ng}^{-1}$ of soil). Irrigation was performed using water with electrical conductivity - ECw of $0.5 \mathrm{dS} \mathrm{m} \mathrm{m}^{-1}$ for the control and $5.0 \mathrm{dS} \mathrm{m}^{-1}$ for the other treatments. The growth and production of sunflower cv. BRS 324 were reduced when the crop was irrigated with water of electrical conductivity of $5.0 \mathrm{dS} \mathrm{m}^{-1}$, independent of the cationic nature of water; nitrogen fertilization did not attenuate the deleterious effects of salt stress caused by irrigation waters of $5.0 \mathrm{dS} \mathrm{m} \mathrm{m}^{-1}$ on sunflower $\mathrm{cv}$. BRS 324; The methods of comparison of means through contrasts and Tukey's test were efficient and can be used together to evaluate the growth and the production of sunflower.
\end{abstract}

KEYWORDS: Helianthus anпииs L. Salt stress. Nitrogen fertilization

\section{INTRODUCTION}

Sunflower (Helianthus annuus L.) belongs to the family Asteraceae, is an oleaginous that has been attracting special attention all over the world, due to the high content of oil found in its achenes, whose composition stands out for being rich in polyunsaturated fatty acids, especially linoleic acid and also as a potential source of protein (ZOBIOLE et al., 2010). In addition, sunflower can be used as a raw material for the food industry in the form of flour and oil, concentrate and protein isolates, serves as a melliferous and ornamental plant and can be used in the manufacture of animal feed (SANTOS JÚNIOR et al., 2011).

Its main products are the oil produced by its seeds and animal feed, besides being widely used in human food in the form of flours and oil, protein concentrates and isolates, as a honey plant, as ornamental plant and it can also be used in the production of biodiesel (CORRÊA et al., 2008).

The Brazilian semi-arid region has welldefined climatic characteristics, with scarce and irregular rainfalls, besides high evapotranspiration. Thus, the best way to guarantee the agricultural production is through irrigation. However, in this region, most of the waters used in irrigation have high salt contents (LIMA et al., 2008), and electrical conductivity may exceed $4.5 \mathrm{dS} \mathrm{m}^{-1}$ (ALVES et al., 2011). Considering that the offer of good-quality water resources has been increasingly reduced, the use of saline water in agriculture must be considered as an important alternative.

The use of water with excess of salts, however, may limit plant growth and production because of the reduction in the osmotic potential of the soil solution and also cause ionic toxicity, nutritional imbalances or both, due to the excessive accumulation of certain ions in plant tissues, especially chloride and sodium. These effects result in serious changes in plant metabolism, reflecting reduced growth and crop production (KHAN; PANDA, 2008; NEVES et al., 2009). However, the effects of the salts on the plants can vary according to the species, cultivar of the same species, types of salts in water and salinity level, intensity and duration of stress, stage of crop development, edaphoclimatic conditions, irrigation management and fertilization as well as interaction between them (GARCIA et al., 2010). 
In order to minimize the deleterious effects caused by irrigation water salinity on sunflower growth and yield, various strategies have been studied, especially the use of nitrogen $(\mathrm{N})$ fertilizers (BISCARO et al., 2008; NOBRE et al., 2010; NOBRE et al., 2011; LIMA et al., 2014), because N performs important physiological functions in the formation of organic compounds, particularly amino acids, proteins, co-enzymes, nucleic acids, vitamins and chlorophyll, among others (CHAVES et al., 2011).

In view of the above, this study aimed to evaluate the growth and production of sunflower cv. BRS 324 irrigated with water of different cationic nature and salinity levels under nitrogen fertilization.

\section{MATERIAL AND METHODS}

The experiment was carried in pots adapted as drainage lysimeters, under open field conditions, in the experimental area of the Center of Technology and Natural Resources of the Federal University of Campina Grande (CTRN/UFCG), in the municipality of Campina Grande-PB, Brazil, situated at the local geographical coordinates of $7^{\circ} 15^{\prime} 18^{\prime \prime} \mathrm{S}, 35^{\circ} 52^{\prime} 28^{\prime}$ ' $\mathrm{W}$ and mean altitude of 532 $\mathrm{m}$.

The experimental design was randomized blocks, arranged in a $5 \times 5$ factorial scheme, with three replicates, using five combinations of salinity and cationic nature of the water - $\mathrm{S}\left(\mathrm{S}_{1}-\mathrm{Control} ; \mathrm{S}_{2}\right.$ - $\mathrm{NaCl} ; \mathrm{S}_{3}-\mathrm{CaCl}_{2} ; \mathrm{S}_{4}-\mathrm{KCl}$ and $\mathrm{S}_{5}$ $\mathrm{NaCl}+\mathrm{CaCl}_{2}+\mathrm{MgCl}_{2}$ ), in which the $\mathrm{ECw}$ used in the irrigations was $0.5 \mathrm{dS} \mathrm{m}^{-1}$ for the control and $5.0 \mathrm{dS}$ $\mathrm{m}^{-1}$ for the other treatments, prepared with different sources of salts, all in the form of chloride, and $\mathrm{N}$ doses $-\mathrm{N}\left[\mathrm{N}_{1}-50 ; \mathrm{N}_{2}-75 ; \mathrm{N}_{3}-100 ; \mathrm{N}_{4}-125\right.$ and $\mathrm{N}_{5}-150 \mathrm{mg}$ of $\mathrm{N} \mathrm{kg}^{-1}$ of soil, considering recommendation of Novais et al. (1991) - $100 \mathrm{mg} \mathrm{N}$ $\mathrm{kg}^{-1}$ for assays in pots.

The different types of water used in irrigation were obtained through the dissolution of chloride salts of sodium $(\mathrm{NaCl})$, calcium $\left(\mathrm{CaCl}_{2} \cdot 2 \mathrm{H}_{2} \mathrm{O}\right)$, potassium $(\mathrm{KCl})$ and magnesium $\left(\mathrm{MgCl}_{2} \cdot 6 \mathrm{H}_{2} \mathrm{O}\right)$ in water from the public supply system, according to the pre-established treatments, whose amount was determined taking into consideration the relationship between $\mathrm{ECw}$ and the concentration of salts $\left(10 * \mathrm{mmol}_{\mathrm{c}} \mathrm{L}^{-1}=1 \mathrm{dS} \mathrm{m}^{-1}\right)$ suggested by Richards (1954). After preparing the types of water, a portable conductivity meter was used to calibrate the ECw. The respective types of water were stored in plastic barrels with capacity for $200 \mathrm{~L}$.

We used seeds of the sunflower cv. BRS 324 , an early variety with cycle of approximately 100 days, high oil content (varying between 45 and $49 \%$ ) in the achenes, and mean yield of $1,500 \mathrm{~kg} \mathrm{ha}^{-}$ ${ }^{1}$ (EMBRAPA, 2013).

Plants were cultivated in pots adapted as lysimeters with capacity for $100 \mathrm{~L}$, filled with a 2.0 $\mathrm{kg}$ layer of crushed stone (size zero), followed by $100 \mathrm{~kg}$ of soil material $(0-20 \mathrm{~cm})$ properly pounded to break up clods, classified as eutrophic Grey Argisol (sandy clay loam), from the district of São José da Mata (Campina Grande-PB), whose physico-chemical characteristics (Table 1) were determined at the Laboratory of Irrigation and Salinity of the CTRN/UFCG, according to the methodology of Claessen (1997).

At the bottom of the lysimeters, a $4 \mathrm{~mm}$ diameter drain was connected to a hole to allow drainage; the upper tip of the drain was involved with a nonwoven geotextile (Bidim OP 30) to avoid obstruction by soil material and, below the drain, a container was placed to collect the drained water which permitted estimation of water consumed by the crop.

Table 1. Physical and chemical characteristics of the soil used in the experiment

\begin{tabular}{|c|c|c|c|c|c|c|c|c|c|c|}
\hline \multirow{3}{*}{$\begin{array}{l}\text { Density } \\
\left(\mathrm{kg} \mathrm{dm}^{-3}\right)\end{array}$} & \multirow{3}{*}{$\begin{array}{l}\text { Total } \\
\text { porosity } \\
(\%)\end{array}$} & \multirow{2}{*}{\multicolumn{2}{|c|}{$\begin{array}{l}\text { Water content } \\
(\%)\end{array}$}} & \multirow{3}{*}{$\begin{array}{c}\text { Availabl } \\
\text { e water } \\
(\%)\end{array}$} & \multicolumn{6}{|c|}{ Exchange complex } \\
\hline & & & & & $\mathrm{Ca}^{2+}$ & $\mathrm{Mg}^{2+}$ & $\mathrm{Na}^{+}$ & $\mathrm{K}^{+}$ & $\mathrm{pH}_{\mathrm{s}}$ & $\mathrm{EC}_{\mathrm{se}}$ \\
\hline & & $\begin{array}{l}0.33 \\
\mathrm{~atm}\end{array}$ & $\begin{array}{l}15.0 \\
\mathrm{~atm}\end{array}$ & & \multicolumn{4}{|c|}{$\ldots \ldots \ldots\left(\mathrm{cmol}_{\mathrm{c}} \mathrm{kg}^{-1}\right) \ldots \ldots \ldots \ldots$} & - & $\left(\mathrm{dS} \mathrm{m} \mathrm{m}^{-1}\right)$ \\
\hline 1.14 & 57.93 & 14.00 & 4.87 & 9.13 & 1.52 & 1.95 & 0.38 & 0.07 & $\begin{array}{c}4.8 \\
4\end{array}$ & 0.20 \\
\hline
\end{tabular}

Fertilization with nitrogen, potassium and phosphorus was performed based on the recommendation of Novais et al. (1991) corresponding to 100,150 and $300 \mathrm{mg}$ of $\mathrm{N}, \mathrm{K}_{2} \mathrm{O}$ and $\mathrm{P}_{2} \mathrm{O}_{5} \mathrm{~kg}^{-1}$ of soil, respectively, using potassium chloride, single superphosphate, monoammonium 
phosphate and urea. Phosphorus was applied in three periods, 2/3 (single superphosphate) applied as basal dose, which corresponded to $125 \mathrm{~g}$ of single superphosphate, and $1 / 3$ as monoammonium phosphate (MAP), divided into 2 equal applications via fertigation, at 10 and 20 days after emergence (DAE), using $9.62 \mathrm{~g}$ of MAP in each application. Potassium fertilization was applied along with the nitrogen, divided into 3 applications via fertigation in intervals of 10 days, from 10 DAE on. Each application consisted of $8.62 \mathrm{~g}$ of potassium chloride and, in the treatment $\mathrm{N}_{3}\left(100 \mathrm{mg}\right.$ of $\mathrm{N} \mathrm{kg}^{-1}$ of soil), $4.85 \mathrm{~g}$ of urea in the first two applications to complement the $\mathrm{N}$ supplied by the MAP, and $7.41 \mathrm{~g}$ in the last application. In other treatments of $\mathrm{N}$ the amounts of urea were adjusted in accordance with the dose.

Sowing was performed on November 2, 2014 , by planting 10 seeds at the depth of $0.04 \mathrm{~m}$. At 18 days after sowing (DAS), the first thinning was performed, leaving only three plants per pot, i.e., those with best vigor (with greater physiological potential and uniform growth), and at 34 DAS a new thinning was performed, leaving one plant per pot.

The soil was maintained at field capacity through daily irrigations, based on the water consumption obtained using the water balance method, i.e., the applied volume minus the drained volume, plus a mean leaching fraction of 0.10 (LIMA et al., 2014).

The effects of the treatments on the sunflower cv. BRS 324 were determined based on plant height $(\mathrm{PH})$, stem diameter (SD), stem dry matter (SDM), leaf dry matter (LDM), external capitulum diameter (ECD) and phytomass of achenes (PA). Stem diameter (SD) and plant height $(\mathrm{PH})$ were measured at 70 DAS (transition phase between filling and maturation of achenes). SD was determined at $5 \mathrm{~cm}$ from the base of the plant, whereas $\mathrm{PH}$ was measured from the base of the plant until the apical bud using a tape.

In the quantification of leaf dry matter (LDM) and stem dry matter (SDM), the plants were collected and separated into leaves and stem, and then placed in paper bags. Subsequently, the material was dried in a forced-air oven at temperature of $60{ }^{\circ} \mathrm{C}$ for 48 hours until constant weight.

The external capitulum diameter (ECD) was evaluated by measuring with a millimetric ruler the horizontal and vertical diameters, to obtain the arithmetic mean. The phytomass of achenes (PA) was obtained based on the production of each plant, evaluated after harvesting the chapters at 85 DAS.
The obtained data were subjected to analysis of variance by $\mathrm{F}$ test. When significant, orthogonal contrasts and test of comparison of means (Tukey test at 0.05 probability level) were applied for the factor "cationic nature of the water" and regression analysis was performed for the factor "nitrogen doses", using the statistical software SISVARESAL version 5.3 (FERREIRA, 2011). The contrasts were defined as follows: $\hat{y}_{1}\left(S_{1}\right.$ vs $S_{2} ; S_{3}$; $\left.\mathrm{S}_{4} ; \mathrm{S}_{5}\right) ; \hat{y}_{2}\left(\mathrm{~S}_{2}\right.$ vs $\left.\mathrm{S}_{3}\right) ; \hat{y}_{3}\left(\mathrm{~S}_{2}\right.$ vs $\left.\mathrm{S}_{4}\right) ; \hat{y}_{4}\left(\mathrm{~S}_{5}\right.$ vs $\mathrm{S}_{2} ; \mathrm{S}_{3}$; $\left.\mathrm{S}_{4}\right)$.

\section{RESULTS AND DISCUSSION}

The analysis of variance shows significant influence of the factor cationic nature of the water on the variables: plant height, stem diameter, stem dry matter, leaf dry matter, external capitulum diameter and phytomass of achenes (Table 2). For the factor $\mathrm{N}$ doses (ND), there was significant effect for the variables: plant height and leaf dry phytomass and, for the interaction between the cationic nature of the irrigation water and the $\mathrm{N}$ doses ( $\mathrm{S} \times \mathrm{ND}$ ), there was no significant effect on any of the studied variables.

According to the data of plant height $(\mathrm{PH})$, there was significant effect of the irrigation using water with different types of salts and, based on the test of comparison of means (Tukey), the use of water of low salinity level $\left(S_{1}\right)$ in the irrigation of sunflower resulted in statistically superior values of PH $(101.13 \mathrm{~cm})$, in relation to the other types of salts $\left(S_{2} ; S_{3} ; S_{4}\right.$ and $\left.S_{5}\right), 61.76,63.06,65.2$ and 64.5 $\mathrm{cm}$, respectively. Similar results were obtained by Lima et al. (2016), who evaluated the growth of castor bean, cv. 'BRS Energia', as a function of the cationic nature of the irrigation water, and observed at 20 DAS that the height of plants subjected to irrigation using water composed of different cations $\left(\mathrm{Na}^{+} ; \mathrm{Ca}^{2+} ; \mathrm{Na}^{+}+\mathrm{Ca}^{2+} ; \mathrm{K}^{+} ; \mathrm{Na}^{+}+\mathrm{Ca}^{2+}+\mathrm{Mg}^{2+}\right)$ was not significantly influenced $(\mathrm{p}>0.05)$ by the different cations present in the irrigation water. Decreasing trends for plant height were also verified by Travassos et al. (2011) after irrigating Embrapa $122 / \mathrm{V}-2000$ sunflower plants with saline waters of 0.5 to $5.0 \mathrm{dS} \mathrm{m}^{-1}$ (prepared only with $\mathrm{NaCl}$ (without iodine), observed a maximum plant height of the order of $141.29 \mathrm{~cm}$ when irrigated with $\mathrm{ECw}$ of 0.5 $\mathrm{dS} \mathrm{\textrm {m } ^ { - 1 }}$ at 38 days after transplanting; the minimum height of plants was of the order of $90.37 \mathrm{~cm}$ when irrigated with ECw of $5.0 \mathrm{dS} \mathrm{m}^{-1}$ at 37 DAT. 
Table 2. Summary of the analysis of variance for plant height $(\mathrm{PH})$, stem diameter (SD), stem dry matter (SDM), leaf dry matter(LDM), at 70 days after sowing, and external capitulum diameter (ECD) and phytomass of achenes (PA) of sunflower plants cultivated under different types of salinity and nitrogen doses

\begin{tabular}{|c|c|c|c|c|c|c|c|}
\hline \multirow{2}{*}{$\begin{array}{c}\text { Source of } \\
\text { variation/Cont } \\
\text { rasts }\end{array}$} & \multirow{2}{*}{$\begin{array}{l}\mathrm{D} \\
\mathrm{F}\end{array}$} & \multicolumn{6}{|c|}{ Mean square } \\
\hline & & $\mathrm{PH}$ & SD & $\mathrm{SDM}^{1}$ & $\mathrm{LDM}^{1}$ & ECD & $\mathrm{PA}^{1}$ \\
\hline Blocks & 2 & $337.62^{\mathrm{ns}}$ & $11.79^{\mathrm{ns}}$ & $118.42^{\mathrm{ns}}$ & $124.32^{\mathrm{ns}}$ & $8.93^{\text {ns }}$ & $116.32^{\mathrm{ns}}$ \\
\hline Cationic & 4 & & & & & & \\
\hline $\begin{array}{l}\text { composition } \\
\text { of water } \\
\text { (CCW) }\end{array}$ & & $4245.04^{* *}$ & $239.47^{* *}$ & $2185.28^{* * *}$ & $2148.85^{* *}$ & $333.03^{* *}$ & $6636.62^{* * *}$ \\
\hline$\hat{\mathrm{y}}_{1}$ & 1 & $16875.00^{* *}$ & $941.48^{* *}$ & $8713.47^{* *}$ & $8554.68^{* *}$ & $1304.16^{* *}$ & $26515.23^{* *}$ \\
\hline$\hat{\mathrm{y}}_{2}$ & 1 & $12.67^{\mathrm{ns}}$ & $0.93^{\text {ns }}$ & $0.01^{\mathrm{ns}}$ & $3.33^{\mathrm{ns}}$ & $2.85^{\mathrm{ns}}$ & $2.95^{\mathrm{ns}}$ \\
\hline$\hat{\mathrm{y}}_{3}$ & 1 & $88.40^{\text {ns }}$ & $12.33^{\mathrm{ns}}$ & $12.98^{\mathrm{ns}}$ & $34.13^{\text {ns }}$ & $26.60^{\text {ns }}$ & $28.91^{\mathrm{ns}}$ \\
\hline$\hat{\mathrm{y}}_{4}$ & 1 & $49.08^{\mathrm{ns}}$ & $7.25^{\mathrm{ns}}$ & $7.60^{\mathrm{ns}}$ & $21.35^{\mathrm{ns}}$ & $20.33^{\text {ns }}$ & $20.87^{\mathrm{ns}}$ \\
\hline $\begin{array}{c}\text { Nitrogen } \\
\text { doses (ND) }\end{array}$ & 4 & $464.24^{*}$ & $9.74^{\mathrm{ns}}$ & $109.92^{\mathrm{ns}}$ & $128.85^{*}$ & $7.46^{\mathrm{ns}}$ & $99.86^{\mathrm{ns}}$ \\
\hline $\begin{array}{c}\text { Interaction } \\
\text { (CCW x ND) }\end{array}$ & 16 & $187.23^{\text {ns }}$ & $7.88^{\text {ns }}$ & $72.87^{\mathrm{ns}}$ & $88.22^{\mathrm{ns}}$ & $10.58^{\mathrm{ns}}$ & $37.53^{\text {ns }}$ \\
\hline Residual & 48 & 165.56 & 5.33 & 51.81 & 52.57 & 11.25 & 104.27 \\
\hline CV (\%) & & 18.09 & 17.88 & 23.22 & 22.86 & 20.12 & 16.33 \\
\hline
\end{tabular}

$\mathrm{S}_{1}=$ Control; $\mathrm{S}_{2}=\mathrm{NaCl} ; \mathrm{S}_{3}=\mathrm{CaCl}_{2} ; \mathrm{S}_{4}=\mathrm{KCl} ; \mathrm{S}_{5}=\mathrm{NaCl}+\mathrm{CaCl}_{2}+\mathrm{MgCl}_{2} ; \hat{\mathrm{y}}_{1}\left(\mathrm{~S}_{1}\right.$ vs $\left.\mathrm{S}_{2} ; \mathrm{S}_{3} ; \mathrm{S}_{4} ; \mathrm{S}_{5}\right) ; \hat{\mathrm{y}}_{2}\left(\mathrm{~S}_{2}\right.$ vs $\left.\mathrm{S}_{3}\right) ; \hat{y}_{3}\left(\mathrm{~S}_{2}\right.$ vs $\left.\mathrm{S}_{4}\right) ; \hat{\mathbf{y}}_{4}\left(\mathrm{~S}_{5}\right.$ vs $\mathrm{S}_{2} ;$ $\mathrm{S}_{3} ; \mathrm{S}_{4}$ ); DF - Degrees of freedom; CV - Coefficient of variation; Significant at 0.05 (*) and at $0.01(* *)$ probability levels; (ns) Not significant; (1) data transformed to $\sqrt{ } \mathrm{x}$.
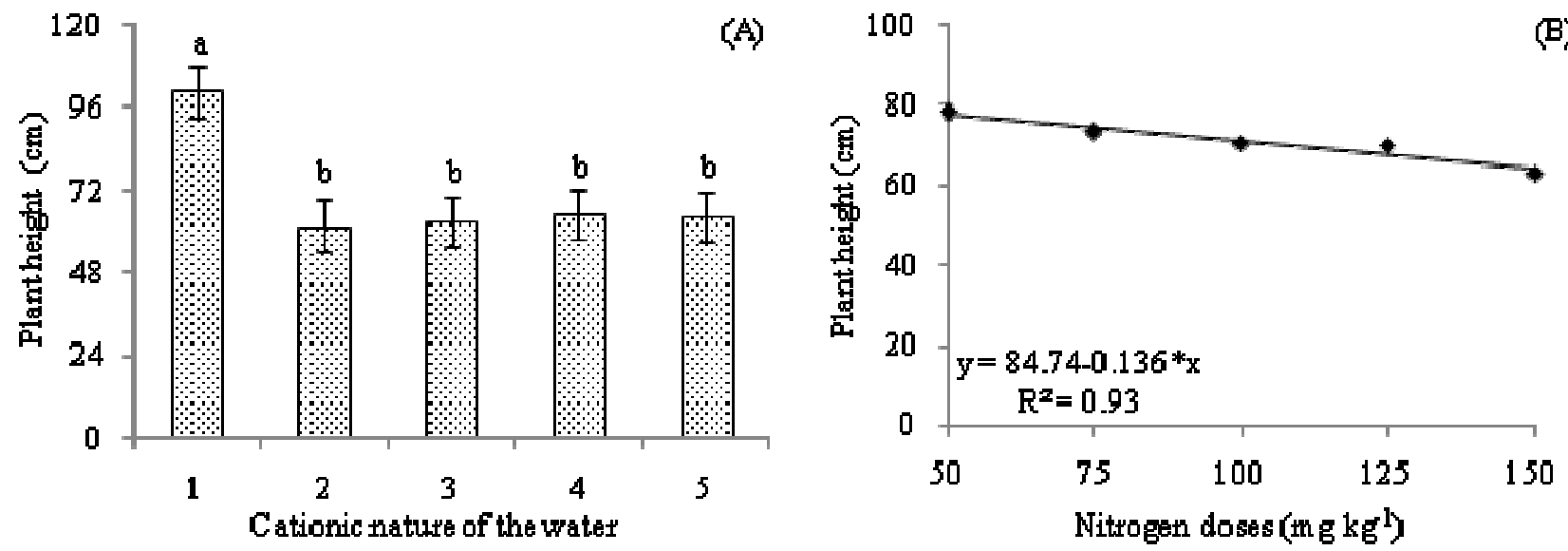

$1=\mathrm{Control} ; 2=\mathrm{NaCl} ; 3=\mathrm{CaCl}_{2} ; 4=\mathrm{KCl} ; 5=\mathrm{NaCl}+\mathrm{CaCl}_{2}+\mathrm{MgCl}_{2} ; \mathrm{Means}$ followed by different letters indicate that the treatments differ by Tukey test, $\mathrm{p}<0.05$. Bars represent the standard error of the mean $(n=3)$.

Figure 1. Height of sunflower plants as a function of the cationic nature of the water (A) and nitrogen doses (B) at 70 days after sowing.

Based on the contrasts of means for plant height (Table 2), there was significant effect for the contrast $\hat{y}_{1}\left(S_{1}\right.$ versus $\left.S_{2} ; S_{3} ; S_{4} ; S_{5}\right)$ and, based on the estimation of mean (Table 3), plants in the treatment with application of low salinity water $(0.5$ $\mathrm{dS} \mathrm{m}^{-1}$ ) showed an increment in $\mathrm{PH}$ of $37.50 \mathrm{~cm}$, in relation to those under ECW of $5.0 \mathrm{dS} \mathrm{m}^{-1}\left(\mathrm{~S}_{2} ; \mathrm{S}_{3} ; \mathrm{S}_{4}\right.$ and $S_{5}$ ) at 70 DAS. Thus, the marked reduction in the stem diameter of the sunflower cultivated at the highest ECw level $\left(5.0 \mathrm{dS} \mathrm{m}^{-1}\right)$ can be attributed to a decrease in the water potential of the soil solution caused by excess soluble salts in the root zone, which promotes a decrease in turgescence and results in decreased cell expansion (KHALID; SILVA, 2010). Additionally, plants tend to close their stomata to reduce water losses through transpiration, resulting in lower photosynthetic rate and contributing to the reduction of growth of the species under such stress. Santos et al. (2012) also claim that this tendency of decrease in $\mathrm{PH}$ under salt 
stress conditions can be attributed to the fact that the plant, in order to adjust osmotically, spends a certain amount of energy for the accumulation of sugars, organic acids and ions in the vacuole, the energy that could be used for growth. These results agree with those of Nobre et al. (2010), who observed that the increase in the salinity of the irrigation water with composition of $\mathrm{NaCl}$ and $\mathrm{ECw}$ varying from 0.5 to $4.9 \mathrm{dS} \mathrm{m}^{-1}$ reduced the height of sunflower, cv. Embrapa 122/V-2000, at 26 and 50 DAS.

Table 3. Estimation of mean for plant height $(\mathrm{PH})$, stem diameter (SD), stem dry mater (SDM) and leaf dry mater (LDM), at 70 days after sowing, and external capitulum diameter (ECD) and phytomass of achenes (PA) of sunflower plants irrigated using water of different types of salinity

\begin{tabular}{ccccccc}
\hline \multirow{2}{*}{$\mathrm{FV}$} & \multicolumn{7}{c}{ Estimation of mean } \\
\cline { 2 - 7 } & $\mathrm{PH}$ & SD & SDM & LDM & ECD & PA \\
\hline$\hat{y}_{1}$ & 37.50 & 8.85 & 26.94 & 26.70 & 10.42 & 47.00 \\
$\hat{y}_{2}$ & $\mathrm{~ns}$ & $\mathrm{~ns}$ & $\mathrm{~ns}$ & $\mathrm{~ns}$ & $\mathrm{~ns}$ & $\mathrm{~ns}$ \\
$\hat{\mathrm{y}}_{3}$ & $\mathrm{~ns}$ & $\mathrm{~ns}$ & $\mathrm{~ns}$ & $\mathrm{~ns}$ & $\mathrm{~ns}$ & $\mathrm{~ns}$ \\
$\hat{\mathrm{y}}_{4}$ & $\mathrm{~ns}$ & $\mathrm{~ns}$ & $\mathrm{~ns}$ & $\mathrm{~ns}$ & $\mathrm{~ns}$ & $\mathrm{~ns}$ \\
\hline
\end{tabular}

$\hat{\mathrm{y}}_{1}\left(\mathrm{~S}_{1} \mathrm{vs}_{2} ; \mathrm{S}_{3} ; \mathrm{S}_{4} ; \mathrm{S}_{5}\right) ; \hat{\mathrm{y}}_{2}\left(\mathrm{~S}_{2}\right.$ vs $\left.\mathrm{S}_{3}\right) ; \hat{\mathrm{y}}_{3}\left(\mathrm{~S}_{2}\right.$ vs $\left.\mathrm{S}_{4}\right) ; \hat{\mathrm{y}}_{4}\left(\mathrm{~S}_{5}\right.$ vs $\left.\mathrm{S}_{2} ; \mathrm{S}_{3} ; \mathrm{S}_{4}\right) ;\left(\right.$ ns) not significant; $\mathrm{S}_{1}=$ Control; $\mathrm{S}_{2}=\mathrm{NaCl} ; \mathrm{S}_{3}=\mathrm{CaCl}{ }_{2} ; \mathrm{S}_{4}=\mathrm{KCl}$; $\mathrm{S}_{5}=\mathrm{NaCl}+\mathrm{CaCl}_{2}+\mathrm{MgCl}_{2}$

Regarding the contrasts of mean $\hat{y}_{2}\left(S_{2}\right.$ versus $\left.S_{3}\right), \hat{y}_{3}\left(S_{2}\right.$ versus $\left.S_{4}\right)$ and $\hat{y}_{4}\left(S_{5}\right.$ versus $S_{2}$; $\left.\mathrm{S}_{3} ; \mathrm{S}_{4}\right)$, there was no significant effect. Thus, according to results, it's possible that sodium, calcium, potassium and magnesium acted in a similar way on sunflower growth.

As to the $\mathrm{N}$ fertilization, plant height fitted to a decreasing linear model, according to the regression equation (Figure 1B). At the $\mathrm{N}$ dose of $50 \mathrm{mg} \mathrm{kg}^{-1}$, plant growth in height was equal to $78.4 \mathrm{~cm}$, while at the dose of $150 \mathrm{mg}$ $\mathrm{kg}^{-1}$ plant growth in height was equal to 63.13 $\mathrm{cm}$. This result indicates a decrease of the order of $19.47 \%$, which is equivalent to a reduction of $4.86 \%$ per increment of $25 \mathrm{mg} \mathrm{kg}^{-1}$ in the dose of $\mathrm{N}$. This result differs from those obtained by Guedes Filho et al. (2013), who studied sunflower cv. Embrapa $122 / \mathrm{V}-2000$ as a function of salinity and $\mathrm{N}$ doses (40 to $100 \mathrm{~kg}$ $\mathrm{ha}^{-1}$ ) under field conditions and observed that maximum plant height was approximately 130 $\mathrm{cm}$, with the application of $100 \mathrm{~kg} \mathrm{ha}^{-1}$ of $\mathrm{N}$. Such divergence observed in the study of Guedes Filho et al. (2013) is possibly due to genetic differences in the cultivars and the cultivation conditions, because it was carried out under field conditions, whereas the present study was conducted in pots, with limited soil volume and space for the development of the crop.
In a similar way to the $\mathrm{PH}$, it was verified by the comparison of means that the cationic nature of irrigation water had a significant influence on the diameter of the sunflower plants evaluated at 70 DAS (Table $2)$. For irrigation using water with different ionic composition (Figure 2A), the use of $\mathrm{S}_{1}$ (control) in the irrigation of sunflower plants resulted in statistically superior values of SD $(20.00 \mathrm{~mm})$ in relation to the other types of salts $\left(\mathrm{S}_{2} ; \mathrm{S}_{3} ; \mathrm{S}_{4}\right.$ and $\left.\mathrm{S}_{5}\right)$.

The lower growth in stem diameter of the sunflower plants probably occurred because the plants were subjected to a stress precisely in the phenological stage (vegetative phase) in which their metabolic activities are maximal (LARCHER, 2004). Lima et al. (2016), evaluating the growth of castor bean, cv. 'BRS Energia', as a function of the cationic nature of the irrigation water $\left(\mathrm{Na}^{+} ; \mathrm{Ca}^{2+} ; \mathrm{Na}^{+}+\mathrm{Ca}^{2+} ; \mathrm{K}^{+}\right.$; $\left.\mathrm{Na}^{+}+\mathrm{Ca}^{2+}+\mathrm{Mg}^{2+}\right)$, at 20 days after sowing, also observed that stem diameter was negatively affected, regardless of the composition of the irrigation water. When evaluating the effects of irrigation with saline waters (ECw: 0.6 to 4.5 $\mathrm{dS} \mathrm{m}{ }^{-1}$, prepared with the addition of $\mathrm{NaCl}$ ) in the growth and production components of sunflower cv. Embrapa 122/V-2000, Ribeiro et al. (2015) also verified that there was a negative effect of saline stress on the stem diameter. 

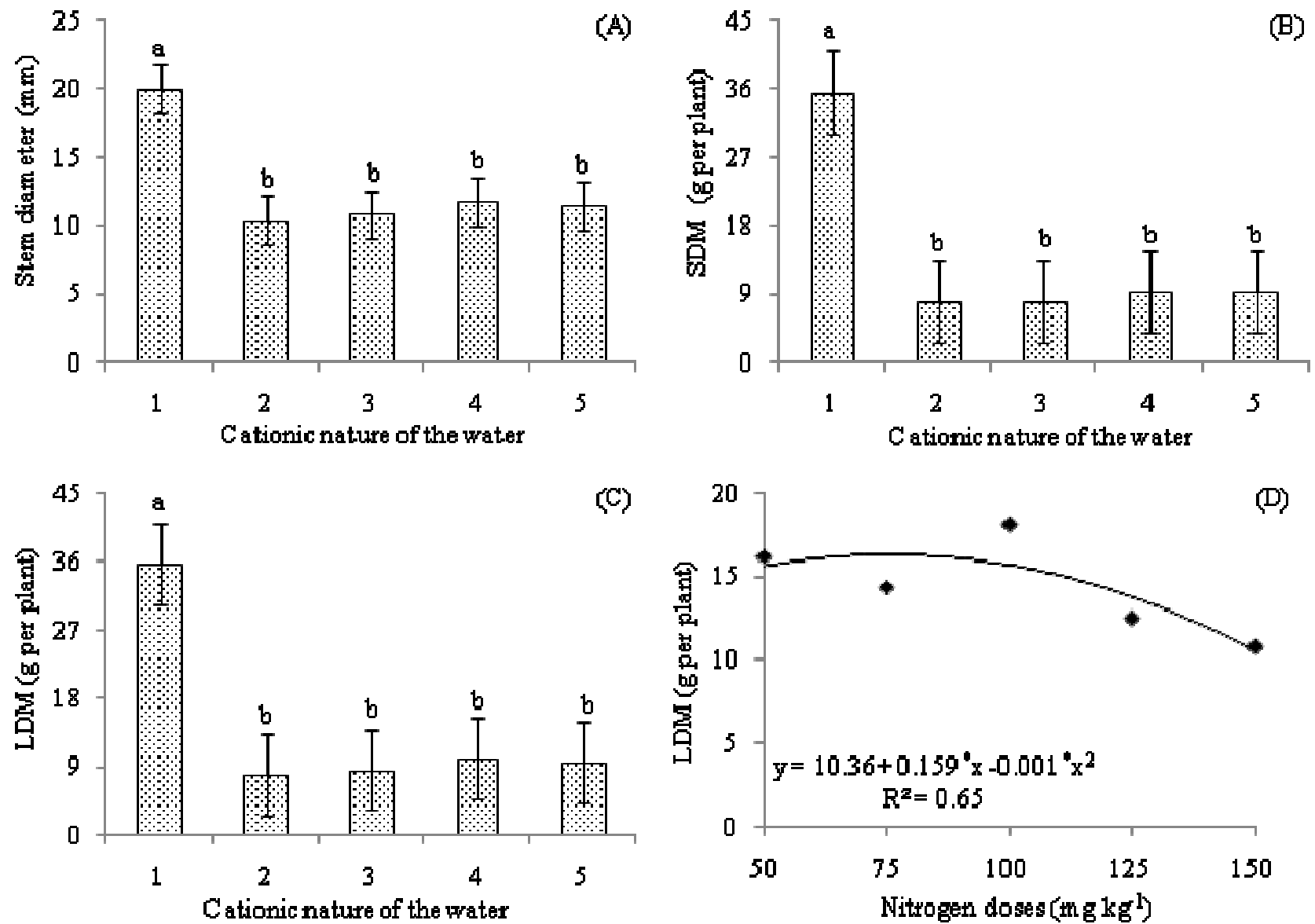

$1=\mathrm{Control} ; 2=\mathrm{NaCl} ; 3=\mathrm{CaCl}_{2} ; 4=\mathrm{KCl} ; 5=\mathrm{NaCl}+\mathrm{CaCl}_{2}+\mathrm{MgCl}_{2} ;$ Means followed by different letters means that the treatments differ by Tukey test, $\mathrm{p}<0.05$. Bars represent the standard error of the mean $(n=3)$.

Figure 2. Stem diameter of sunflower plants as a function of the cationic nature of the water (A) at 70 days after sowing, stem dry matter- SDM (B) and leaf dry matter- LDM of sunflower plants as a function of the cationic nature of the water (C) and nitrogen doses (D)

According to the analysis of the contrasts of means (Table 2), there was significant effect for the treatment $\hat{y}_{1}\left(S_{1}\right.$ vs $S_{2} ; S_{3} ; S_{4}$ and $\left.S_{5}\right)$, compared with plants subjected to irrigation with water of the treatment $\mathrm{S}_{1}$ (control). For plants under irrigation using water of different ionic composition $\left(\mathrm{S}_{2} ; \mathrm{S}_{3} ; \mathrm{S}_{4}\right.$ and $\mathrm{S}_{5}$ ), the $\mathrm{SD}$ was superior, with mean estimate of $8.85 \mathrm{~mm}$ (Table 3 ).

For the other contrasts of mean $\left(\mathrm{S}_{2}\right.$ versus $\left.S_{3}\right),\left(S_{2}\right.$ versus $\left.S_{4}\right)$ and $\left(S_{5}\right.$ versus $\left.S_{2} ; S_{3} ; S_{4}\right)$, there was no significant effect on $\mathrm{SD}$, characterizing the similar action of these types of salts $\left(\mathrm{Na}^{+}, \mathrm{Ca}^{2+}, \mathrm{K}^{+}\right.$ and $\mathrm{Na}^{+}+\mathrm{Ca}^{2+}+\mathrm{Mg}^{+2}$ ) on sunflower growth. Based on these results of $\mathrm{SD}$, the effect of salinity on the growth of sunflower plants is more related to the $\mathrm{ECW}$, so that plants irrigated using water of low salinity, $\mathrm{S}_{1}\left(0.5 \mathrm{dS} \mathrm{m}^{-1}\right)$, were superior to those that received water of higher salinity level, $S_{2}, S_{3}, S_{4}$ and $\mathrm{S}_{5}\left(5.0 \mathrm{dS} \mathrm{m} \mathrm{m}^{-1}\right)$. Guedes Filho et al. (2013), evaluating the influence of irrigation using water with electrical conductivity ranging from 0.15 to 4.5 $\mathrm{dS} \mathrm{m}^{-1}$ and $\mathrm{N}$ fertilization on the growth of sunflower, cv. Embrapa 122/V-2000, under field conditions, observed reductions in stem diameter of 0.96 and $0.82 \mathrm{~mm}$ per unit increase in the electrical conductivity of the irrigation water, at 60 and 75 DAE, respectively. Decreasing tendencies for stem diameter in sunflower plants were also found by Travassos et al. (2012), after irrigating sunflower plants (cultivars: Helio 863, Embrapa 122/V-2000, Catissol 01 and Multissol) with saline waters of 0.6 to $5.4 \mathrm{dS} \mathrm{m}^{-1}$.

Stem dry matter- SDM (Figure 2B) differed statistically according to the test of comparison of means (Tukey). When plants were irrigated with $\mathrm{S}_{1}$ water (control), the SDM production (35.64 g) was significantly higher in comparison to plants irrigated with water of the treatments $S_{2}, S_{3}, S_{4}$ and $S_{5}$, with mean decreases in SDM production of 77.56, 77.44, 73.87 and $73.52 \%$.

According to the summary of the analysis of variance for the contrasts of means referring to stem dry matter (Table 2), there was significant effect for the contrast $\hat{y}_{1}\left(S_{1}\right.$ vs $S_{2} ; S_{3} ; S_{4}$ and $\left.S_{5}\right)$, at 70 DAS. 
Based on the estimation of mean (Table 3), plants subjected to the treatment $\mathrm{S}_{1}$ (control, ECw of 0.5 $\mathrm{dS} \mathrm{m}^{-1}$ ) showed increment of $26.94 \mathrm{~g}$, in comparison to plants cultivated under irrigation using waters of different types of salts: $\mathrm{S}_{2}, \mathrm{~S}_{3}, \mathrm{~S}_{4}$ and $\mathrm{S}_{5}\left(\mathrm{Na}^{+}, \mathrm{Ca}^{+2}\right.$, $\mathrm{K}^{+}$and $\mathrm{Na}^{+}+\mathrm{Ca}^{2+}+\mathrm{Mg}^{2+}$ ) and $\mathrm{ECw}$ of $5.0 \mathrm{dS} \mathrm{m} \mathrm{m}^{-1}$. Marenco Centeno et al. (2014), working with sunflower under water salinity levels of 0.7 to 4.7 $\mathrm{dS} \mathrm{m}^{-1}$ and $\mathrm{N}$ fertilization, observed a decrease of $68.26 \%$ in shoot dry matter production of plants irrigated with water of higher salinity level, in relation to those irrigated with water of lower salinity level.

According to the test of comparison of means Tukey (Figure 2C), the leaf dry matter $(\mathrm{LDM})$ production $(35.8 \mathrm{~g})$ of plants irrigated with $\mathrm{S}_{1}$ water (control) was statistically superior to those of plants under irrigation with water of different cationic nature $\left(S_{2}, S_{3}, S_{4}\right.$ and $\left.S_{5}\right), 8.0,8.66,10.13$ and $9.6 \mathrm{~g}$, respectively. However, comparing the different cations present in the irrigation water, there was no significant difference.

As observed for SDM, based on the analysis of the contrasts for the variable LDM (Table 2), there was significant effect for the contrast $\hat{y}_{1}\left(S_{1}\right.$ vs $\mathrm{S}_{2} ; \mathrm{S}_{3} ; \mathrm{S}_{4}$ and $\mathrm{S}_{5}$ ), at 70 DAS. According to Table 3, LDM was higher in plants irrigated with $S_{1}$ water(control, $\mathrm{ECw}$ of $0.5 \mathrm{dS} \mathrm{m} \mathrm{m}^{-1}$ ), with mean of $26.70 \mathrm{~g}$, in relation to those irrigated with water of different cationic nature $\left(S_{2}, S_{3}, S_{4}\right.$ and $\left.S_{5}\right)$ at $E C w$ of $5.0 \mathrm{dS} \mathrm{m}^{-1}$. This effect on leaf dry matter can be understood as a probable mechanism of adjustment of the plant to reduce the effects of salinity, because plants may suffer morphological or physiological modifications, such as reduction of biomass, when subjected to salt stress. According to Asch et al. (2000), the presence of high contents of $\mathrm{Na}^{+}$and $\mathrm{Cl}^{-}$ in the irrigation water or in the soil can cause disruption in the homeostasis of the water potential and ionic imbalance on the soil-plant interface and lead to toxicity in the plant, altering its growth and dry matter production, besides promoting reduction in the absorption of nutrients.

According to the data referring to the cationic nature of the water, taking into consideration the absolute values of LDM (Figure 2C), the treatment with highest leaf dry matter production was water with potassium in its composition $\left(\mathrm{S}_{4}\right)$ and the lowest LDM production was observed in the treatment of water with sodium in its composition $\left(\mathrm{S}_{2}\right)$, which may indicate that the excess of sodium in the composition of the applied water damages the allocation of leaf phytomass in sunflower.
As to the effect of $\mathrm{N}$ doses on LDM production (Figure 2D), according to the regression equation, the data fitted to a quadratic model. The increase in the $\mathrm{N}$ dose from 50 to $75 \mathrm{mg} \mathrm{kg}^{-1}$ resulted in an increment in LDM production, with maximum value $(16.68 \mathrm{~g})$ estimated at the dose of $79.5 \mathrm{mg} \mathrm{kg}^{-1}$. From this point on, there is a tendency of reduction in LDM production as the $\mathrm{N}$ doses increased, demonstrating negative effects of $\mathrm{N}$, which can be associated with the increase in the amount of salts in the soil solution.

For the external capitulum diameter - ECD (Figure 3A), sunflower plants that received irrigation with $S_{1}$ water (control) were statistically different, being significantly superior to those obtained in plants irrigated with water of different cationic nature, treatments $S_{2}, S_{3}, S_{4}$ and $S_{5}$, with reductions of the order of $45.16,42.70,37.64$ and $41.17 \%$, respectively.

Table 2 shows the summary of the analysis of variance for the contrasts of means referring to the external capitulum diameter. There was significant effect only for the contrast $\hat{y}_{1}\left(S_{1}\right.$ vs $S_{2}$; $\mathrm{S}_{3} ; \mathrm{S}_{4}$ and $\mathrm{S}_{5}$ ). Based on the estimation of mean (Table 3), plants subjected to the treatment $S_{1}$, water of lower salinity level $\left(0.5 \mathrm{dS} \mathrm{m} \mathrm{m}^{-1}\right)$, showed increment of $10.42 \mathrm{~cm}$, in comparison to those cultivated in the treatments $\mathrm{S}_{2}, \mathrm{~S}_{3}, \mathrm{~S}_{4}$ and $\mathrm{S}_{5}(\mathrm{ECW}$ of $5.0 \mathrm{dS} \mathrm{m}$ ). Thus, despite the variation of the cationic nature of the irrigation water $\left(\mathrm{NaCl}, \mathrm{CaCl}_{2}\right.$, $\mathrm{KCl}, \mathrm{NaCl}+\mathrm{CaCl}_{2}+\mathrm{MgCl}_{2}$ ), the deleterious effect on ECD occurred in a similar way for all treatments under study, data obtained (Table 3), show that the sunflower cv. BRS 323 has its production adversely affected by the variation in saline levels (ECw of 0.5 to $5.0 \mathrm{dS} \mathrm{m}^{-1}$ ).

The reduction observed in ECD of sunflower plants cultivated at the highest water salinity level $\left(\mathrm{ECW}=5.0 \mathrm{dS} \mathrm{\textrm {m } ^ { - 1 } )}\right.$ is probably a consequence of the osmotic effect of the dissolved salts, which reduce the osmotic potential of the soil solution and inhibit the conduction of water to the cells, characterizing the water stress in the plants (FLOWERS, 2004), thus causing changes in the photosynthetic and biochemical processes, and consequently the production of photoassimilates decrease, a fact that possibly affected negatively the formation of the sunflower stand. Nobre et al. (2010) found that the effect of salt stress (ECw: 0.5 to $4.9 \mathrm{dS} \mathrm{m} \mathrm{m}^{-1}$, obtained from sodium chloride addition) on the growth and flowering of sunflower cv. Embrapa 122/V-2000, that the external chapter diameter was negatively influenced. When analyzing the sunflower cv. Embrapa 122 / V-2000, under different saline levels (ECw of 0.15 to $4.5 \mathrm{dS}$ 
$\mathrm{m}^{-1}$ ) Guedes Filho et al. (2015) also observed that the diameter of the chapter was inhibited by the water salinity. According to the test of comparison of means Tukey (Figure 3B), the phytomass of achenes - PA of plants irrigated by the treatment $S_{1}$ (control) was statistically superior, exhibiting PA of
$52.17 \mathrm{~g}$, in relation to those under irrigation with water of different cationic nature, $S_{2}, S_{3}, S_{4}$ and $S_{5}$ $\left(\mathrm{Na}^{+}, \mathrm{Ca}^{2+} ; \mathrm{K}^{+}\right.$and $\left.\mathrm{Na}^{+}+\mathrm{Ca}^{2+}+\mathrm{Mg}^{2+}\right)$, leading to values of $4.23,4.85,6.19$ and $5.40 \mathrm{~g}$, respectively, characterizing reductions of $91.89,90.68,88.12$ and $89.63 \%$ compared with the control treatment $\left(S_{1}\right)$.
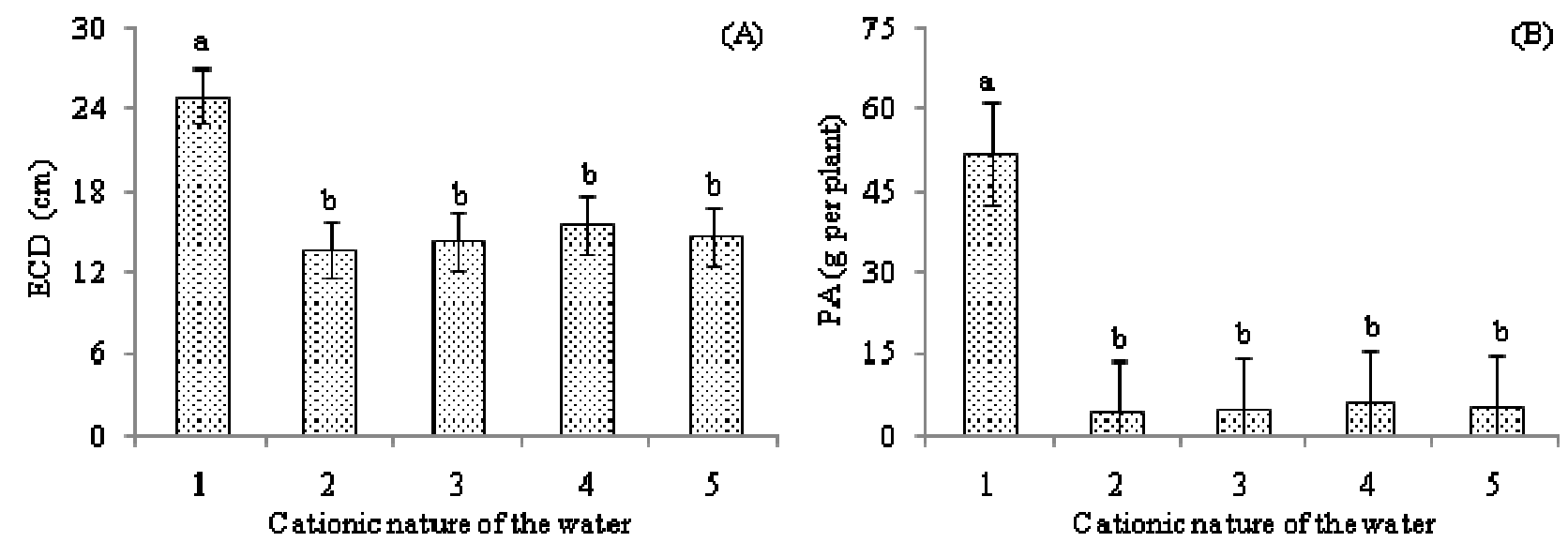

$1=$ Control $; 2=\mathrm{NaCl} ; 3=\mathrm{CaCl}_{2} ; 4=\mathrm{KCl} ; 5=\mathrm{NaCl}+\mathrm{CaCl}_{2}+\mathrm{MgCl}_{2} ;$ Means followed by different letters indicate that the treatments differed by Tukey test, $\mathrm{p}<0.05$. Bars represent the standard error of the mean $(n=3)$.

Figure 3. External capitulum diameter - ECD (A) and phytomass of achenes - PA (B) of sunflower, as a function of the cationic nature of the water

Table 2 shows the summary of the analysis of variance for the contrasts of means referring to PA. There was significant effect for the contrast $\hat{y}_{1}$ $\left(\mathrm{S}_{1}\right.$ vs $\mathrm{S}_{2} ; \mathrm{S}_{3} ; \mathrm{S}_{4}$ and $\left.\mathrm{S}_{5}\right)$. Based on the estimate of the mean (Table 3 ), plants subjected to the treatment $\mathrm{S}_{1}\left(0.5 \mathrm{dS} \mathrm{m}^{-1}\right)$ showed mean increment of $47.00 \mathrm{~g}$, in comparison to those cultivated under irrigation in the treatments $\mathrm{S}_{2}, \mathrm{~S}_{3}, \mathrm{~S}_{4}$ and $\mathrm{S}_{5}\left(\mathrm{Na}^{+}, \mathrm{Ca}^{2+} ; \mathrm{K}^{+}\right.$and $\left.\mathrm{Na}^{+}+\mathrm{Ca}^{2+}+\mathrm{Mg}^{2+}\right)$, with $\mathrm{ECw}$ of $5.0 \mathrm{dS} \mathrm{m}{ }^{-1}$. In the other contrasts of mean, $\hat{y}_{2}\left(S_{2}\right.$ versus $\left.S_{3}\right), \hat{y}_{3}\left(S_{2}\right.$ versus $\left.S_{4}\right)$ and $\hat{y}_{4}\left(S_{5}\right.$ versus $\left.S_{2} ; S_{3} ; S_{4}\right)$, there was no significant effects. Thus, the PA exhibited a similar behavior in the analysis of the cationic nature of the water, indicating that its reduction is more related to the salt stress caused by the ECw.

Nobre et al. (2010), working with the production variables of sunflower, observed that, from the ECw of $0.5 \mathrm{dS} \mathrm{m}^{-1}$ on, there is a decrease in the production of achenes, which corroborates the results obtained in the present study. According to Marrenco Centeno et al. (2014), this reduction can be closely related to the effects of salinity on the plants, which leads to losses of yield and quality, or total loss of the production, caused by the concentration of soluble salts or salinity, which are limiting factors for the development of most crops.

\section{CONCLUSIONS}

The growth and production of sunflower $\mathrm{cv}$. BRS 324 are reduced when the crop is irrigated with water of electrical conductivity of $5.0 \mathrm{dS} \mathrm{m}$, independently of the cationic nature of the water;

Nitrogen fertilization does not attenuate the deleterious effects of salt stress caused by irrigation water of electrical conductivity of $5.0 \mathrm{dS} \mathrm{m}^{-1}$ on sunflower cv. BRS 324;

The methods of comparison of means through contrasts and Tukey's test are efficient and can be used together to evaluate the growth and production of sunflower.

\section{ACKNOWLEDGMENTS}

To the National Council for Scientific and Technological Development - CNPq, for granting the scholarship to the first author.

RESUMO: No semiárido brasileiro é comum encontrar águas com elevadas concentrações salinas e com variação na sua composição catiônica. Neste sentido, objetivou-se com este trabalho, avaliar o crescimento e os componentes de produção do girassol cv. BRS 324, em função da irrigação com água de diferentes salinidades e natureza catiônica associada a doses de nitrogênio, em experimento conduzido em vasos, sob condições abertas de campo, no 
município de Campina Grande, PB, no delineamento de blocos ao acaso, em esquema fatorial 5 x 5 , com três repetições, sendo cinco tratamentos de salinidade e natureza catiônica da água - $\mathrm{S}\left(\mathrm{S}_{1}-\mathrm{Testemunha} ; \mathrm{S}_{2}-\mathrm{NaCl} ; \mathrm{S}_{3}-\mathrm{CaCl} \mathrm{N}_{2} ; \mathrm{S}_{4}-\mathrm{KCl}\right.$ e $\mathrm{S}_{5}-\mathrm{NaCl}+\mathrm{CaCl}_{2}+\mathrm{MgCl}_{2}$ ) combinados com cinco doses de nitrogênio $\left(50 ; 75 ; 100 ; 125\right.$ e $150 \mathrm{mg}$ de $\mathrm{N} \mathrm{kg} \mathrm{kg}^{-1}$ de solo). Utilizou-se na irrigação, água com condutividade elétrica - CEa de $0,5 \mathrm{dS} \mathrm{m}^{-1}$ para a testemunha $\left(\mathrm{S}_{1}\right)$ e $5,0 \mathrm{dS} \mathrm{m}^{-1}$ para os demais tratamentos. O crescimento e a produção do girassol cv. BRS 324 foram reduzidos quando a cultura é irrigada com água de condutividade elétrica de 5,0 dS m $\mathrm{m}^{-1}$, independente da natureza catiônica da água; a adubação nitrogenada não atenuou os efeitos deletérios do estresse salino causado por irrigação com água de $5,0 \mathrm{dS} \mathrm{m}^{-1}$ sobre o girassol cv. BRS 324 . Os métodos de comparação de médias através de contrastes e teste de Tukey foram eficientes e podem ser utilizados em conjunto para avaliar o crescimento e a produção de girassol.

PALAVRAS-CHAVE: Helianthus annuus L. Estresse salino. Fertilização nitrogenada

\section{REFERENCES}

ALVES, M. S.; SOARES, T. M.; SILVA, L. T.; FERNANDES, J. P.; OLIVEIRA, M. L. A.; PAZ, V. P. S. Estratégias de uso de água salobra na produção de alface em hidroponia NFT. Revista Brasileira de

Engenharia Agrícola e Ambiental, Campina Grande, v. 15, n. 5, p. 491-498, mai. 2011.

https://doi.org/10.1590/S1415-43662011000500009

ASCH, F.; DINGKUHN, M.; DORFFING, K. Salinity increases $\mathrm{CO}_{2}$ assimilation but reduces growth in field grown irrigated rice. Plant and Soil, Dordrecht, v. 218, n. 1/2, p. 1-10. 2000.

https://doi.org/10.1023/A:1014953504021

BISCARO, G. A.; MACHADO, J. R.; TOSTA, M. S.; MENDONÇA, V.; SORATTO, R. P.; CARCALHO, L. A. Adubação nitrogenada em cobertura no girassol irrigado nas condições de Cassilândia MS. Ciência e Agrotecnologia, Lavras, v. 32, n. 5, p. 1366-1373, set./out., 2008. https://doi.org/10.1590/S141370542008000500002

CHAVES, L. H. G.; GHEYI, H. R.; RIBEIRO, S. Consumo de água e eficiência do uso para cultivar de mamona Paraguaçu submetida à fertilização nitrogenada. Revista de Engenharia Ambiental, Espírito Santo do Pinhal, v. 8, n. 1, p. 126-133, jan./mar. 2011.

CLAESSEN, M. E. C. (org.). Manual de métodos de análise de solo. 2.ed. rev. atual. Rio de Janeiro: Embrapa-CNPS, 1997. 212p.

CORRÊA, I. M.; MAZIERO, J. V. G.; ÚNGARO, M. R.; BERNARDI, J. A.; STORINO, M. Desempenho de motor diesel com mistura de biodiesel de óleo de girassol. Ciência e Agrotecnologia, Lavras, v. 32, n. 3, p. 923-928, mai/jun. 2008. https://doi.org/10.1590/S1413-70542008000300033

EMBRAPA - Empresa Brasileira de Pesquisa Agropecuária. Cultivar de girassol BRS 324: variedade com alto teor de óleo e precocidade. EMBRAPA Soja. (Folder), Londrina, 2013.

FERREIRA, D. F. Sisvar: A computerstatisticalanalysis system. Ciência e Agrotecnologia, Lavras, v. 35, n. 6, p. 1039-1042, nov./dez. 2011. https://doi.org/10.1590/S1413-70542011000600001

FLOWERS, T. J. Improving crop salt tolerance. Journal of Experimental Botany, Lancaster, v. 55, n. 396, p. 307- 319, jan.2004. https://doi.org/10.1093/jxb/erh003

GARCIA, G. de O.; NAZÁRIO, A. A.; MORAES, W. B.; GONÇALVES, I. Z.; MADALÃO, J. C. Respostas de genótipos de feijoeiro à salinidade. Engenharia na Agricultura, Viçosa, v.18, n.4, p.330-338, jul/ago. 2010. https://doi.org/10.13083/1414-3984 
GUEDES FILHO, D. H.; SANTOS, J. B. dos; GHEYI, H. R.; CAVALCANTE, L. F.; FARIAS, H. L. de. Biometria do girassol em função da salinidadeda águade irrigação e da adubação nitrogenada. Revista Brasileira de Agricultura Irrigada, Fortaleza, v. 7, n. 5, p. 277-289, out.2013. https://doi.org/10.7127/rbai.v7n500174

GUEDES FILHO, D. H.; SANTOS, J. B. dos; GHEYI, H. R.; CAVALCANTE, L. F.; SANTOS JUNIOR, J. A. Componentes de produção e rendimento do girassol sob irrigaçãocom águas salinas e adubação nitrogenada. Irriga, v. 20, n. 3, p. 514-527, jul./set. 2015. https://doi.org/10.15809/irriga.2015v20n3p514

KHALID, A.; SILVA, J. A. T. Yield, essential oil and pigment content of Calendula officinalis L. flower heads cultivated under salt stress conditions. Scientia Horticulturae, Amsterdam, v. 126, n. 2, p. 297-305, sept. 2010. https://doi.org/10.1016/j.scienta.2010.07.023

KHAN, M. H.; PANDA, S. K. Alterations in root lipid peroxidation and antioxidative responses in two rice cultivars under NaCl-salinity stress. Acta Physiologiae Plantarum, Bangalore, v. 30, n. 1, p. 81-89, jan. 2008. https://doi.org/10.1007/s11738-007-0093-7

LARCHER, W. Ecofisiologia vegetal. São Carlos: RiMa, 2004. 531p.

LIMA, C. B.; SANTOS FILHO, S. V.; SANTOS, M. A.; OLIVEIRA, M. Desenvolvimento da mamoneira, cultivada em vasos, sob diferentes níveis de salinidade da água em LatossoloVermelho-amarelo eutrófico. Revista Caatinga, Mossoró, v. 21, n. 5, p. 50-56, dez.2008.

LIMA, G. S. de; GHEYI, H. R.; NOBRE, R. G.; XAVIER, D. A.; SOARES, L. A. dos A.; CAVALCANTE, L. F.; SANTOS, J. B. Emergence, growth, and flowering of castor beans as a function of the cationic composition of irrigation water. Semina: Ciências Agrárias, Londrina, v.37, n.2, p.651-664, abr. 2016. https://doi.org/10.5433/1679-0359.2016v37n2p651

LIMA, G. S. de; NOBRE, R. G.; GHEYI, H. R.; SOARES, L. A. dos A.; SILVA, S. S. da. Respostas morfofisiológicas da mamoneira, em função da salinidade da água de irrigação e adubação nitrogenada. Revista Irriga, Botucatu, v. 19, n. 1, p. 130-136, jan./mar. 2014. https://doi.org/10.15809/irriga.2014v19n1p130

MARRENCO CENTENO, C. R.; SANTOS, J. B. dos; XAVIER, D. A.; AZEVEDO, C. A. V. de; GHEYI, H. R. Componentes de produção do girassol Embrapa 122-V2000 sob salinidade da água e adubação nitrogenada. Revista Brasileira de Engenharia Agrícola e Ambiental, Campina Grande, v. 18, suplemento, p. 39-45, dez. 2014. https://doi.org/10.1590/1807-1929/agriambi.v18nsupps39-s45

NEVES, A. L. R.; LACERDA, C. F.; GUIMARÃES, F. V. A.; HERNANDEZ, F. F. F.; SILVA, F. B.; PRISCO, J. T.; GHEYI, H. R. Acumulação de biomassa e extração de nutrientes por plantas de feijão de corda irrigadas com água salina em diferentes estádios de desenvolvimento. Ciência Rural, Santa Maria, v. 39, n. 3 p. 758-765, mai/jun.2009. https://doi.org/10.1590/S0103-84782009005000014

NOBRE, R. G.; GHEYI, H. R.; CORREIA, K. G.; SOARES. F. A. L.; ANDRADE, L. O de. Crescimento e floração do girassol sob estresse salino e adubação nitrogenada. Revista Ciência Agronômica, Fortaleza, v. 41, n. 3, p. 358-365, jul./set.2010. https://doi.org/10.1590/S1806-66902010000300006

NOBRE, R. G.; GHEYI, H. R.; SOARES, F. A. L.; CARDOSO, A. F. Produção de girassol sob estresse salino e adubação nitrogenada. Revista Brasileira de Ciência do Solo, Viçosa, v. 35, v. 3, p. 929-937, mai.jun.2011. https://doi.org/10.1590/S0100-06832011000300027

NOVAIS, R. F.; NEVES, J. C. L.; BARROS, N. F. Ensaio em ambiente controlado. In: OLIVEIRA, A. J. (ed.) Métodos de pesquisa em fertilidade do solo. Brasília: Embrapa-SEA. 1991. p. 189-253. 
RIBEIRO, P. H. P.; SILVA, S.; DANTAS NETO, J.; OLIVEIRA, C. da S.;CHAVES, L. H. G.Crescimento e componentes de produção do girassol em função da irrigação com água salina e adubação nitrogenada. Engenharia na Agricultura, Viçosa, v. 23, n. 1, p. 48-56, jan./fev. 2015. https://doi.org/10.13083/14143984/reveng.v23n1p48-56

RICHARDS, L.A. (ed.) Diagnosis and improvement of saline and alkali soils. USDA, Washington, USA.(USDA. Agriculture Handbook, 60). 1954. 160p.

SANTOS JÚNIOR, J. A.; GHEYI, H. R.; GUEDES FILHO, D. H.; DIAS, N. da S.; SOARES, F. A. L. Cultivo de girassol em sistema hidropônico sob diferentes níveis de salinidade. Revista Ciência Agronômica,

Fortaleza, v. 42, n. 4, p. 842-849, out./dez. 2011. https://doi.org/10.1590/S1806-66902011000400004

SANTOS, B. dos.; FERREIRA, P. A.; OLIVEIRA, F. G. de.; BATISTA, R. O.; COSTA, A. C.; CANO, M. A. O. Produção e parâmetros fisiológicos do amendoim em função do estresse salino. Revista Idesia, Arica, v. 30, n. 2, p. 69-74, mai./ago. 2012. https://doi.org/10.4067/S0718-34292012000200009

TRAVASSOS K. D.; SOARES F. A. L.; GHEYI H. R.; DIAS N. DA S.; NOBRE R. G. Crescimento e produção de flores de girassol irrigado com água salobra. Revista Brasileira de Agricultura Irrigada, v. 5, n. 2, p. 123-133, mar./apr. 2011. https://doi.org/10.7127/rbai.v5n200036

TRAVASSOS, K. D.; GHEYI, H. R.; SOARES, F. A. L.; BARROS, H. M. M.; SILVA, N. D.; UYEDA, C. A.; SILVA, F. V. da. Crescimento e desenvolvimento de variedades de girassol irrigado com água salina. Irriga, Botucatu, v. 1, n. 1, p. 324-339. 2012. https://doi.org/10.15809/irriga.2012v1n01p324

ZOBIOLE, L. H. S.; CASTRO, C. de; OLIVEIRA, F. A. de; OLIVEIRA JUNIOR, A. de. Marcha de absorção de macronutrientes na cultura do girassol. Revista Brasileira de Ciência do Solo, Viçosa, v. 34, n. 2, p. 425 433, mar./apr. 2010. https://doi.org/10.1590/S0100-06832010000200016 